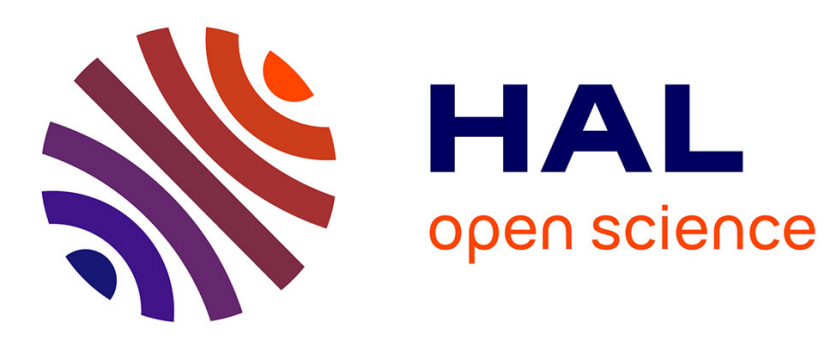

\title{
IFRS for SMEs: A Structured Literature Review
}

Issam Benhayoun, M. Marghich Abdellatif

\section{To cite this version:}

Issam Benhayoun, M. Marghich Abdellatif. IFRS for SMEs: A Structured Literature Review. International Journal of Accounting and Financial Reporting, 2017, 7 (2), 10.5296/ijafr.v7i2.12390 . hal-01910461

\section{HAL Id: hal-01910461 \\ https://hal.science/hal-01910461}

Submitted on 1 Nov 2018

HAL is a multi-disciplinary open access archive for the deposit and dissemination of scientific research documents, whether they are published or not. The documents may come from teaching and research institutions in France or abroad, or from public or private research centers.
L'archive ouverte pluridisciplinaire HAL, est destinée au dépôt et à la diffusion de documents scientifiques de niveau recherche, publiés ou non, émanant des établissements d'enseignement et de recherche français ou étrangers, des laboratoires publics ou privés. 


\title{
IFRS for SMEs: A Structured Literature Review
}

\author{
M. Benhayoun Issam (Corresponding author) \\ Research Laboratory of Management, Finance and Organization Auditing (LAMAFAO) \\ National School of Trade and Management [ENCG] \\ Sidi Mohamed Ben Abdellah University, Fes, Morocco \\ E-mail: issam.benhayoun@usmba.ac.ma
}

\begin{abstract}
M. Marghich Abdellatif
Research Laboratory of Management, Finance and Organization Auditing (LAMAFAO)

National School of Trade and Management [ENCG]

Sidi Mohamed Ben Abdellah University, Fes, Morocco
\end{abstract}

Received: February 12, 2017 Accepted: February 22, 2017 Published: December 31, 2017

doi:10.5296/ijafr.v7i2.12390 URL: https://doi.org/10.5296/ijafr.v7i2.12390

\begin{abstract}
Since its issue in 2009, the IFRS for SMEs have been studied by many researchers. Each one of them performed his research according to a precise perspective and varied methodologies.

The goal behind this article is to present a Structured Literature Review of the most relevant publications (Citation Classics) of the IFRS for SMEs by studying their impact, as well as their contributions, critique and future research path.
\end{abstract}

Keywords: IFRS for SMEs, Structured literature review, Citation classics, Impact analysis

\section{Introduction}

After five years of development of a standard adapted to Small and Medium Sized Entities (SMEs), the IASB issued in July the $9^{\text {th }} 2009$ "IFRS for SMEs". The goal behind is to integrate to the world economy, and more specifically to international capital markets, a group of structures with high potential of development, but to which not enough attention was given in terms of financing despite its importance (Note 1) (OECD, 2004).

The standard is considered as a simplified version of the full IFRS, with 230 pages including a preface, 35 sections, a glossary and a correspondence table of IFRS for SMEs sections with 


\section{Mll Macrothink}

International Journal of Accounting and Financial Reporting

ISSN 2162-3082 2017, Vol. 7, No. 2

the full IFRS. IFRS for SMEs doesn't include some topics like Earnings per share, Non-current Assets Held for Sale and Discontinued Operations ...etc.

According to IASB (2015), an SME is an entity that a) do not have public accountability and b) publish general-purpose financial statements for external users. And an SME has public accountability if:

- its debt or equity instruments are traded in a public market or it is in the process of issuing such instruments for trading in a public market (a domestic or foreign stock exchange or an over-the-counter market, including local and regional markets); or

- It holds assets in a fiduciary capacity for a broad group of outsiders as one of its primary businesses (most banks, credit unions, insurance companies, securities brokers/dealers, mutual funds and investment banks would meet this second criterion).

Therefore the IASB didn't give quantitative criteria (revenues, number of employers, turnover ...etc.) to define SMEs but allows jurisdictions to define their own criteria as well as whether they will implement the standard or not.

Since 2009, many research papers broach the IFRS for SMEs. But the number is still low compared to other IFRS. A simple query on Harzing's Publish or Perish is evocative regarding this aspect. Only 375 papers were published about IFRS for SMEs comparing it to much more than 1000 papers for full IFRS for example.

The aim of our paper is to present a structured literature review (SLR) of the Citation Classics of IFRS for SMEs following the recommendations of Massaro et al. (2016) by answering three main questions:

- How is research for inquiring into IFRS for SMEs developing? ;

- What is the focus and critique of the IFRS for SMEs literature?; and

- What is the future for IFRS for SMEs research?

Our paper is structured as follows: Section 2 give a brief presentation of SLR. Section 3 outlines the methodology followed to undertake our SLR on IFRS for SMEs. Section 4 presents the Results before Section 5 discuss our conclusions.

\section{Structured Literature Reviews}

Literature reviews have different objectives and aims. But in the same time they share some common characteristics namely, collecting, evaluating and presenting the available research evidence (Arskey and O'Malley, 2005, p.20).

We find for example a systematic review, a research synthesis, a meta-analysis ...etc. which could be seen according to Massaro et al. (2016, p.769) to be on a continuum with no rules on one end and a rigid set of rules at the other. 


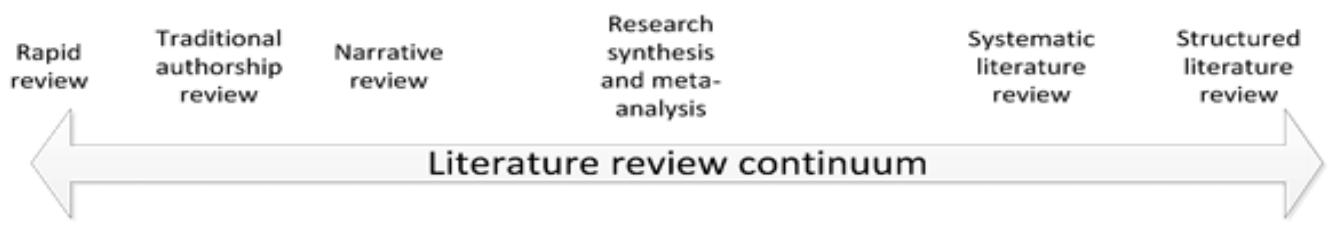

No rules

Rigid rules

Figure 1. The literature review continuum

We notice that SLR is the most demanding one in terms of rules to follow which make it as the most structured contrary to a traditional authorship review for example, which is widely used in research studies, but considered as too subjective (Petticrew and Roberts, 2008). Denyer and Transfield (2006, p. 216) state that:

[...] the most common technique in management research is the traditional literature review in which the researcher summarizes and interprets previous contributions in a subjective and narrative fashion.

Thus, a literature review must have a logical structure and should be based on a precise plan (Hart, 1998, p. 172) following specific steps to perform it (e.g. Dumay, 2014; Guthrie and Parker, 2011; Guthrie et al, 2012). According to Massaro et al (2016, p.171) the SLR's process is as follows:

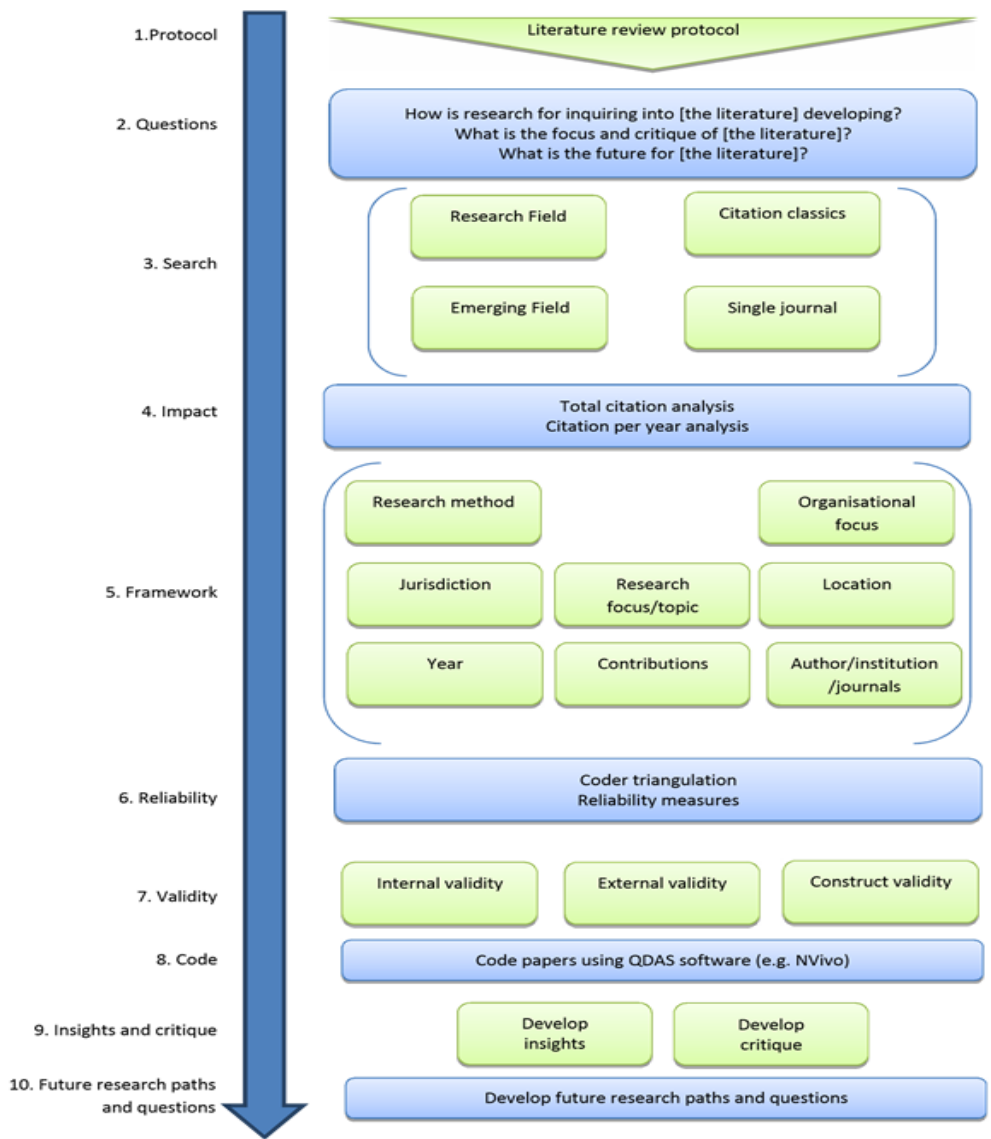

Figure 2. SLR's process 


\section{Macrothink \\ International Journal of Accounting and Financial Reporting \\ ISSN 2162-3082 \\ 2017, Vol. 7, No. 2}

1. Write a literature review protocol;

2. Define the questions that the literature review is setting out to answer;

3. Determine the type of studies and carry out a comprehensive literature search;

4. Measure article impact;

5. Define an analytical framework;

6. Establish literature review reliability;

7. Test literature review validity;

8. Code data using the developed framework;

9. Develop insights and critique through analyzing the dataset; and

10. Develop future research paths and questions.

\section{Methodology}

As presented in Section 2, there is a precise plan and process to follow in order to perform a SLR. Our methodology is based on the process suggested by Massaro et al. (2016).

First of all, we started by establishing a literature review protocol with the aim of documenting the procedure followed, which is widely connected with the aim of increasing research reliability. As Petticrew and Roberts (2008, p. 285) stated "it is essential to write a protocol stating the review question, the methods to be used, the study types and designs which the reviewer intends to locate, and by what means, and how these studies will be appraised and synthesized".

Our Literature review is presented as follows:

- Review question: We had two main questions:

$\checkmark$ What are the different subjects of IFRS for SMEs research studies? and;

What are the main findings and conclusions?

- Methods to be used: The SLR's process

- Study type and design which we intend to locate: The article that have the most impact;

- By what means?: Web of Science

- How these studies will be appraised and synthesized? SLR's steps.

Secondly, we presented the questions that the literature review is setting out to answer in our introduction. As suggested by Massaro et al, (2016, p.774-777) there are three main questions to answer:

- How is research for inquiring into [IFRS for SMEs] developing?

- What is the focus and critique of the [IFRS for SMEs] literature?; and

- What is the future for [IFRS for SMEs] research?

Thirdly, we choose between the four study types suggested by Massaro et al, (2016, p.777) the Citation Classics as our study type because we intend to locate the article with the highest 
impact on the research field. According to Garfield (1977), who initially defined the concept of Citation classics to identify those most frequently cited papers that set the tone for development of a discipline, Citation Classics could be defined as a work whose citation count placed it in the top 1\% of works (Garfield, 2016) or a highly cited publication as identified by the Science Citation Index (SCI) the Social Sciences Citation Index (SSCI), or the Arts \& Humanities Citation Index (A\& HCI) (Garfield, 2016). We choose the $2^{\text {nd }}$ definition as our basic definition because the $1 \%$ criterion isn't reliable as far as the total publication which represents is of 3 to 4 articles which are not a sufficient number to ascertain conclusions of a research. We can locate SCI, SSCI and A\&HCI in Thomson Reuters' Web of Science which is considered as the most widely used database that collects as much information more reliably and with more analysis tools to process information (Martinez et al, 2013, p.1976) and has long been considered the "gold standard" for citation analysis (Harzing and Alakangas, 2015, p. 5).

After, we measure article impact by analyzing three bibliometric indicators, Total Citation (Note 2) (TC), Citation per Year (Note 3) (CPY) and H-Index (Note 4) of the articles, authors and journals. The data was collected by Harzing's Publish or Perish software that is based on Google Scholar database, which is a widely used database and considered as a leading tool in citation analysis. In fact, Google scholar provides a comprehensive coverage, indexes all categories of publications and counts citations from non-peer-reviewed works, such as practitioner magazines, government documents, and newspaper (Dumay, 2014, p. 5). In the first place, we gave a ranking to each publication in terms of each bibliometric indicator for articles, authors and journals and we sum up the rankings to have points for each one. After this, we did another ranking to those points gathering TC, CPY and H-index to establish a Total Ranking.

Afterwards, we define our analytical framework based on our literature review questions in order to analyze each one of them independently. Every question was compounded then from one or many units of analysis to which we attributed a code in order to reduce the data to be analyzed to just those that contains the relevant empirical estimate, test or finding. Our analytical framework as well as our coding is presented as follows:

Literature review questions

\begin{tabular}{lll}
\hline & \multicolumn{1}{l}{ Subject } & Subj \\
\cline { 2 - 3 } $\begin{array}{l}\text { How is research for inquiring into IFRS for SMEs } \\
\text { develop? }\end{array}$ & Location & Loc \\
\cline { 2 - 3 } & Methodology & Meth \\
\hline $\begin{array}{lll}\text { What is the focus and critique of the IFRS for SMEs } \\
\text { literature? }\end{array}$ & Contributions & Cn \\
\cline { 2 - 3 } & Limits \& critics & L\&C \\
\hline What is the future for IFRS for SMEs research? & Future path & FuP
\end{tabular}




\section{$\Lambda$ Macrothink}

International Journal of Accounting and Financial Reporting ISSN 2162-3082

Before starting the analysis we have tested the reliability and validity of our data. To establish reliability we made sure, as recommended by Krippendorff (2013, p.267), that the data collected a) was generated with all conceivable precautions in place against known pollutants, distortions and biases, intentional or accidental, and (b) mean the same thing for everyone who uses them. For that aim, the data source of our articles constitute an impediment to unreliability because unlike Google Scholar as an example that gives different results if we delete the $S$ to IFRS for SMEs for example. Web of Science search for scientific resources by subjects and not by keywords, which makes it a strong tool to assess reliability. We also defined 2015 as a boundary year to ascertain that the generated data will give the same results for everyone who makes the query next time.

As for validity, we determined 2009 as the starting year for our query in order to take into consideration the definitive version of IFRS for SMEs issued by the IASB in July 2009, because if no starting year were determined the results will include articles based just on subjective assumptions and/or a project of the standard. By this, we will be facing the history effect that can bias the internal validity. The latter can also be bias by the selection effect to which the choice of our database is of a greater remedy. In fact, Web of Science is well and truly the best database that locates the Citation Classics which are our sample. We also studied the Construct Validity by studying the convergent validity and we found approximately the same results in the rankings of our articles in terms of bibliometric indicators in other databases like Google Scholar for example.

And finally we analyzed every single article by using the analytical framework compounded of units of analysis to which we attributed codes. The results are presented in the following section.

\section{Results}

The results of the query on Web of Science generated 11 articles (See Appendix 1) considered as Citation Classics of IFRS for SMEs between 2009 and 2015.

As stated in Section 3 we analyzed articles' impact of three bibliometric indicators (TC, CPY and H-Index) of articles, authors and journals. The results show that for:

- Articles: The H-Index is not a relevant indicator to analyze articles because it will be often equal to 1 since the article is usually published in just one journal and by the same authors, in the contrary of authors that we find them in many articles and journals. As for the impact, we found that the article with the greater impact is Implementation of IFRS for SMEs in Emerging Economies: Stakeholder Perceptions in the Czech Republic, Hungary, Romania and Turkey with respectively 38\% and $37 \%$ in terms of TC and CPY. Followed by IFRS FOR SMEs: THE IASB'S DUE PROCESS with $18 \%$ in both TC and CPY and by CRITICAL ANALYSIS OF THE CONTENTS OF THE IFRS FOR SMES - A SOUTH AFRICAN PERSPECTIVE in the third position with $14 \%$ in TC and $8 \%$ in CPY. 


\section{MlMacrothink}

International Journal of Accounting and Financial Reporting

ISSN 2162-3082

2017, Vol. 7, No. 2
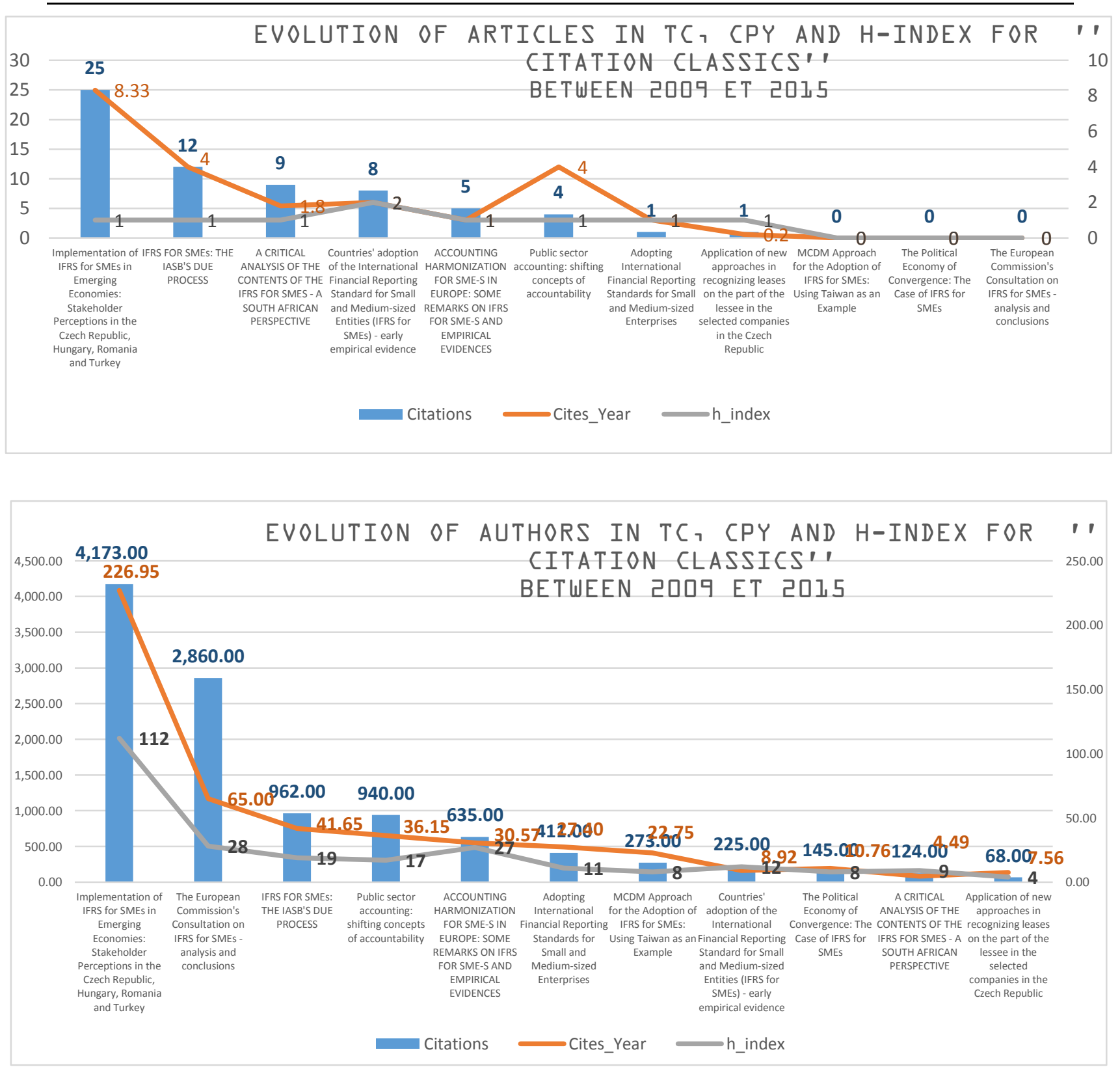

O Authors: The authors with the greater impact are the authors of the article Implementation of IFRS for SMEs in Emerging Economies: Stakeholder Perceptions in the Czech Republic, Hungary, Romania and Turkey, considered as the first article in terms of impact. They are 14 one who participated in that article and are from different countries (Czech Republic, Hungary, Romania ...etc.). Jointly they gathered $4173 \mathrm{TC}$ with an average of 226.95 per year and with the best H-Index of all the authors. Between them ALBU N, ALBU CN, LUKACS J, STROUHAL J and SIPAHI B are in the first position in terms of TC, CPY and H-Index. As for SCHILDBACH T, he is the second author in impact analysis with respectively 1860 and 65 in TC and CPY and individually he is the first one. And in the third position RAM R and NEWBERRY S, the authors of the article IFRS FOR SMEs: THE IASB'S DUE PROCESS with 962 TC and 41.65 CPY. 


\section{Macrothink}

International Journal of Accounting and Financial Reporting

ISSN 2162-3082

2017, Vol. 7, No. 2

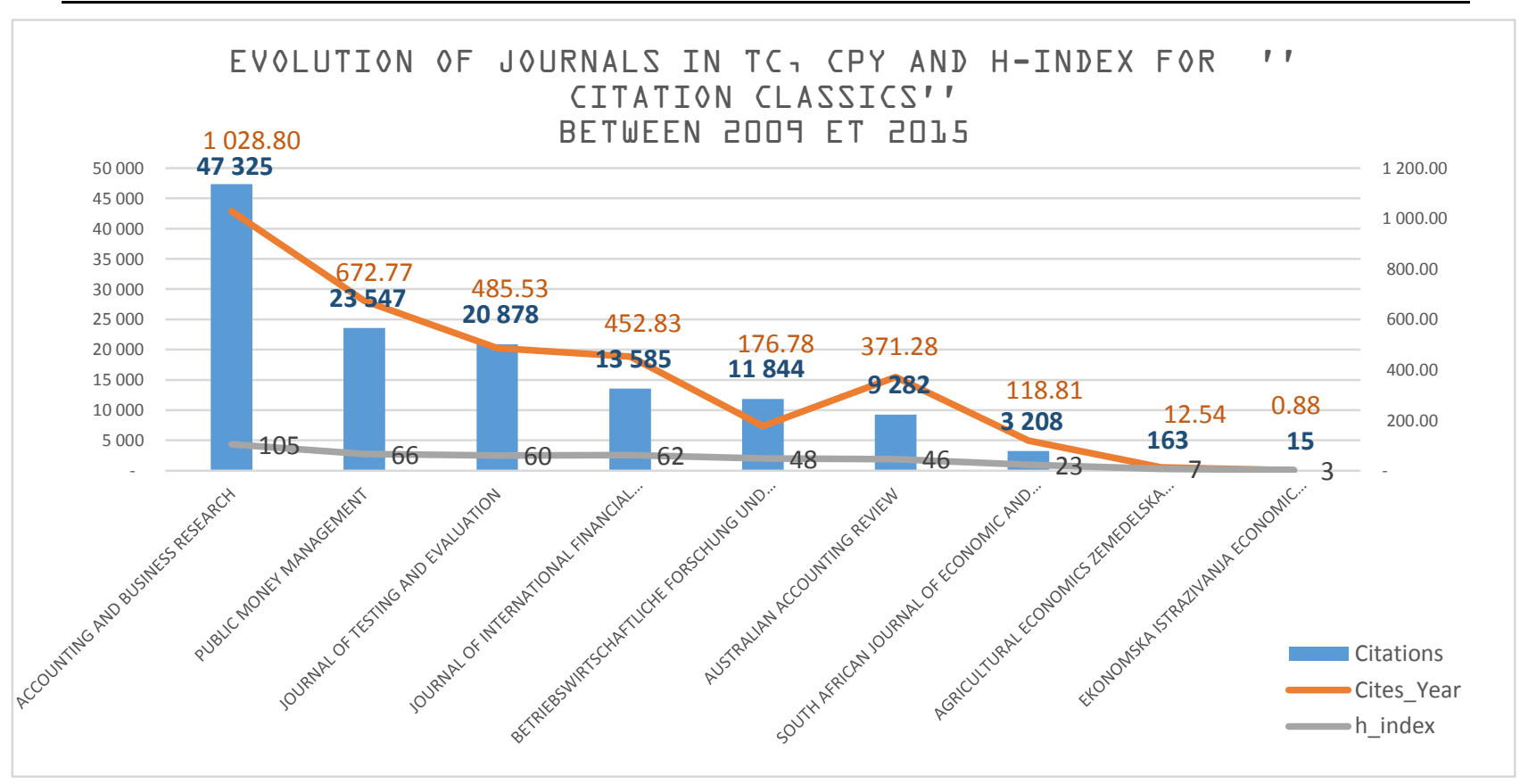

○ Journals: Between the nine journals of our Citation Classics query, the ACCOUNTING AND BUSINESS RESEARCH on which the article Countries' adoption of the International Financial Reporting Standard for Small and Medium-sized Entities (IFRS for SMEs) - early empirical evidence was published, is the one with the more impact with $37325 \mathrm{TC}$ with an average per year of 1028.8 and an H-Index of 105 which is so important in citation analysis. As for PUBLIC MONEY MANAGEMENT on which the article Public sector accounting: shifting concepts of accountability was published, it is placed in the second position with respectively $23547,672.77$ and 66 in terms of TC, CPY and H-Index. The third one is JOURNAL OF TESTING AND EVALUATION that published MCDM Approach for the Adoption of IFRS for SMEs: Using Taiwan as an Example with 20878 TC, 485.53 CPY and 60 in the H-Index.

To sum up, and according to the methodology described in Section 3 on article impact, we established the Appendixes 5 to 7 that ranks the Citation Classics in terms of each of the bibliometric indicators chosen (TC, CPY and H-Index). And ultimately we gave a Total Ranking gathering those bibliometric indicators to assess the final results of our article impact analysis. The following table presents the Total Ranking: 


\begin{tabular}{|c|c|c|c|c|c|}
\hline & \multirow[b]{2}{*}{ Articles } & \multicolumn{3}{|c|}{ TOTAL RANKING } & \multirow{2}{*}{$\begin{array}{l}\text { TOTAL } \\
\text { POINTS }\end{array}$} \\
\hline & & $\begin{array}{c}\text { Total } \\
\text { Citation }\end{array}$ & $\begin{array}{l}\text { Citation } \\
\text { per Year }\end{array}$ & H-Index & \\
\hline 1 & $\begin{array}{l}\text { Implementation of IFRS for SMEs in Emerging Economies: } \\
\text { Stakeholder Perceptions in the Czech Republic, Hungary, Romania } \\
\text { and Turkey }\end{array}$ & 1 & 1 & 1 & 3 \\
\hline 2 & Public sector accounting: shifting concepts of accountability & 3 & 1 & 3 & 7 \\
\hline 3 & $\begin{array}{l}\text { Countries' adoption of the International Financial Reporting Standard } \\
\text { for Small and Medium-sized Entities (IFRS for SMEs) - early } \\
\text { empirical evidence }\end{array}$ & 3 & 3 & 2 & 8 \\
\hline 4 & IFRS FOR SMEs: THE IASB'S DUE PROCESS & 2 & 4 & 5 & 11 \\
\hline 5 & $\begin{array}{l}\text { Adopting International Financial Reporting Standards for Small and } \\
\text { Medium-sized Enterprises }\end{array}$ & 7 & 5 & 6 & 18 \\
\hline 6 & $\begin{array}{l}\text { The European Commission's Consultation on IFRS for SMEs - } \\
\text { analysis and conclusions }\end{array}$ & 4 & 11 & 4 & 19 \\
\hline 7 & $\begin{array}{l}\text { MCDM Approach for the Adoption of IFRS for SMEs: Using Taiwan } \\
\text { as an Example }\end{array}$ & 5 & 7 & 8 & 20 \\
\hline 8 & $\begin{array}{l}\text { A CRITICAL ANALYSIS OF THE CONTENTS OF THE IFRS FOR } \\
\text { SMES - A SOUTH AFRICAN PERSPECTIVE }\end{array}$ & 6 & 6 & 9 & 21 \\
\hline 9 & $\begin{array}{l}\text { ACCOUNTING HARMONIZATION FOR SME-S IN EUROPE: } \\
\text { SOME REMARKS ON IFRS FOR SME-S AND EMPIRICAL } \\
\text { EVIDENCES }\end{array}$ & 6 & 8 & 7 & 21 \\
\hline 10 & The Political Economy of Convergence: The Case of IFRS for SMEs & 7 & 10 & 10 & 27 \\
\hline 11 & $\begin{array}{l}\text { Application of new approaches in recognizing leases on the part of the } \\
\text { lessee in the selected companies in the Czech Republic }\end{array}$ & 8 & 9 & 11 & 28 \\
\hline
\end{tabular}

We conclude in our impact analysis that the article Implementation of IFRS for SMEs in Emerging Economies: Stakeholder Perceptions in the Czech Republic, Hungary, Romania and Turkey is the article with the greatest impact among Citation Classics in terms of the most important and relevant bibliometric indicators. This is could be explained by the number of authors (14) that co-wrote it and their impact (especially $\mathrm{N}$ ALBU, CN ALBU, J STROUHAL ...etc.) as well as their diverse nationalities and organizations even if the journal on which the article was published is of a less impact compared to others (like Accounting and Business Research, Public Money Management ...etc..). We also notice that the subject with the more impact on the field of research studies on IFRS for SMEs is the phenomena of Adoption, Implementation, Convergence or Harmonization, assimilated in our study as Adoption, which could be explained by the importance of the use of this standard in the point of view of Citation Classics' authors.

After article impact we analyzed our papers by taking into consideration our analytical framework and codes in our reading of the papers. And the results is presented in Appendix 8 where we summarized our findings according to the determined analytical framework and with which we will answer our research questions. 


\section{- How is research for inquiring into IFRS for SMEs developing?}

To answer this question we analyzed independently 3 main units of analysis (Subject, Location and Methodology) in addition to a chronological representation of the manner with which the research is developing on Citation Classics' IFRS for SMEs.

\begin{tabular}{rrccc} 
Subjects & \# of articles & \% & Citations & $\%$ \\
\hline Adoption & 5 & $45 \%$ & 39 & $60 \%$ \\
Institutional resources analysis of IFRS for SMEs & 3 & $27 \%$ & 12 & $18 \%$ \\
Content Analysis of IFRS for SMEs & 2 & $18 \%$ & 10 & $15 \%$ \\
IFRS for SMEs and public sector & 1 & $9 \%$ & 4 & $6 \%$
\end{tabular}

We notice that IFRS for SMEs is studied more from the Adoption phenomena perspective than others with a share of $60 \%$ in terms of TC compounding almost the half of the total articles. Whilst Institutional resources analysis of IFRS for SMEs and Content Analysis of IFRS for SMEs has respectively only a small share of $18 \%$ and $15 \%$ in terms of TC.

$\begin{array}{rcccc}\text { Location } & \text { \# of articles } & \text { \% } & \text { Citations } & \% \\ \text { Eastern Europe } & 4 & 40 \% & 25 & 56 \% \\ \text { Africa } & 1 & 10 \% & 9 & 20 \% \\ \text { Asia } & 2 & 20 \% & 6 & 13 \% \\ \text { Oceania } & 2 & 20 \% & 5 & 11 \% \\ \text { N/A } & 1 & 10 \% & 12 & 0 \%\end{array}$

As for the location Eastern Europe is the most location under study in IFRS for SMEs with $56 \%$ in terms of TC with $40 \%$ of the total papers published, that is 4 articles with a total of 25 TC. Albeit we would expect that Africa would have no place in terms of TC, but with just one article in the field it gather $20 \%$ of TC.

\begin{tabular}{rrrrrr} 
Methodology & \# of articles & \% & Citations & $\%$ \\
\hline Qualitative & 2 & $18 \%$ & 31 & $48 \%$ \\
Quantitative & 6 & $55 \%$ & 24 & $37 \%$ \\
Documentary study & 2 & $18 \%$ & 10 & $15 \%$ \\
Literature review & 1 & $9 \%$ & 0 & $0 \%$
\end{tabular}

And finally, the most used methodology in research studies about IFRS for SMEs is the quantitative methodology with a $55 \%$ share of total works and $37 \%$ in TC, but with less impact than the qualitative methodology, with $48 \%$ in terms of $\mathrm{TC}$ that is $31 \mathrm{TC}$, even if it has only a share of $18 \%$ in the published papers. We also noticed that literature reviews has a tiny share of $9 \%$ with no impact at all. 


\section{Mll Macrothink}

International Journal of Accounting and Financial Reporting

ISSN 2162-3082

2017, Vol. 7, No. 2

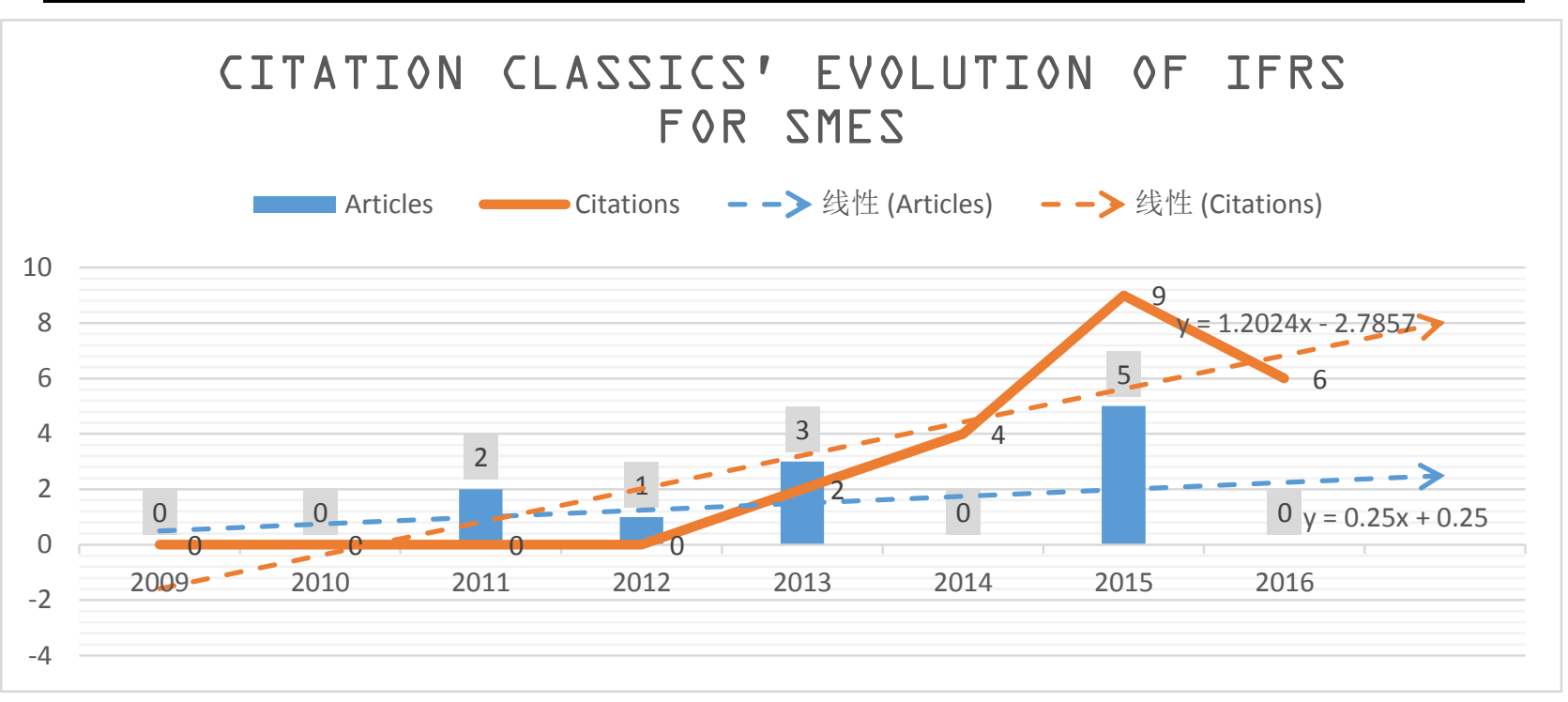

Since its publication year in 2009, no Citation Classics was published about IFRS for SMEs until 2011, which means 2 year of no impactful papers about the standard. Furthermore the scientific community didn't react rapidly by working on and publishing about the standard even if it presents many advantages and opportunities for countries, especially emerging and developing countries. This could be explained by a concentration of published papers in developed economies, that they weren't the primary target of the standard.

In 2011 two articles were published, both about content analysis of IFRS for SMEs' sections followed by only one article in 2012 related to the Harmonization process of the case of Croatian national GAAP and IFRS for SMEs. And researchers started to cite Citation Classics of IFRS for SMEs only after 4 year of its publication that is 2013 , which is not an appropriate timespan on which a standalone standard of its importance would be cited. The same year witnesses the publication of 3 other articles compounded of 2 articles about Institutional resources analysis of IFRS for SMEs which are IFRS FOR SMEs: THE IASB'S DUE PROCESS and The European Commission's Consultation on IFRS for SMEs - analysis and conclusions. As for the third article, it is about the implementation phenomena of the standard on 4 developing and/or emerging countries (Czech Republic, Hungary, Romania and Turkey) by establishing 3 possible scenarios to implement the standard according to the isomorphism phenomena or what is known as the Institutional theory of accounting.

2014 was a year of no publication because the IASB disclose in 2013 that the standard will be revised and many amendments will be issued. But it was a year of citations with the highest degree of TC since its publication in 2009. As for 2015, it was the year with highest rate of publications and Citations with 5 publications, 3 of them is about the Adoption phenomena and the others deal with the political standpoint of Convergence towards IFRS for SMEs gathering 9 citations in total. This is explained by the new amendments issued by the IASB in May 2015 with a planned effectiveness for annual periods beginning on or after 1 January 2017 with permitted earlier application. 
As for the foresights, 2016 and 2017 will witness respectively an average of 2 Citation Classics generating and average of 7 and 8 in terms of TC.

\section{- What is the focus and critique of the IFRS for SMEs literature?}

Many authors have many contributions that differs one from another. The main contributions will presented according to each subject. Starting with the most studied subject, Albu et al. in their article with the highest impact, worked on the implementation process of IFRS for SMEs, and they were the first to establish implementation scenarios in a given country. They were also one of the primary researchers who uses the institutional theory to asses 3 possible scenarios according to isomorphism and they were also one of the 2 articles that qualitatively studied the standard. Liu and Lee, their main contribution is creating a model of adoption based on Multiple Criteria Decision Making Approach (MCDM) and they also proposed 3 further scenarios of implementation. Chand el al. outlined the eventual issues that countries may face in their implementation process. The latter, according to Kaya and Koch, is more favorable in countries without the capacity to develop their own GAAP or they already adopt full IFRS. Their findings demonstrate that IFRS for SMEs guides well and truly to information quality. And finally, for the first and unique time, IFRS for SMEs' adoption was studied under the angle of Harmonization in the article of Baldarelli et al. who compared the Croatian GAAPs with IFRS for SMEs and offers some possible trails of harmonization.

As for the second subject, which is Institutional resources analysis of IFRS for SMEs, 3 authors studied that angle of the standard. Ram and Newsberry criticized the non-meticulous respect of the IASB due process of IFRS for SMEs which lead the IASB to maintain the recognition and measurement criteria of full IFRS even if they are not very appropriate for a simplified version and especially for the primary target of IFRS for SMEs. After analyzing the participation of academics and SMEs of developing economies in the elaboration of the standard, Susela and Samujh concluded that their participation is so slight regarding the role supposed to play in this matter.

Concerning the content analysis subject of IFRS for SMEs, Schute and Buys found that professionals of developing economies are inclined towards the use of the statement of financial position and the statement of comprehensive income in comparison to other financial statements (e.g. statement of cash flows...etc.). Svoboda analyses a specific section of IFRS for SMEs, which is the leases, and he concluded that Leases contracts present some major hurdles in a technical standpoint as far as it is difficult to decide beforehand if the purchase option will be executed or not.

And finally, Newsberry studied the relationship between IFRS for SMEs and the public sector and the role that could be played by the use of the standard in terms of increasing public accountability, which is considered as a novelty in the field.

However, the papers presents some critics and limits that should be underlined. Firstly, Albu et al. didn't offer real empirical evidences about advantages, effects and costs of implementation of IFRS for SMEs. Chand tried to deal with this issue but its main limit is that they didn't give enough attention to stakeholders who could use the standard nor the 
work of Svoboda about the leases in IFRS for SMEs. Kaya and Koch didn't take into consideration the fact that the diffusion of the standard is still an ongoing process as the adopting countries are increasing so the conclusions can't intend definitiveness because the data collected about the development degree of the countries is not reliable since this data was collected from IASB database. As for Devia and Samujh, they didn't provide empirical evidence about the fact that the IASB issue IFRS under the pressure of the lobbies that finance it and Baldarelli et al. didn't assess their harmonization study by deeper analytical tools. Liu and Lee for their part generalized their adoption model according to MCDM approach but without performing tests about external validity to ascertain generalization. Ram and Newsberry did the same thing in judging the IASB of not respecting their due process without comparing for example the IASB due process of IFRS for SMEs with another standard issued by the IASB. But it's not the only critic to their article as far as they could support their findings by quantitative data even if they used a qualitative methodology.

Nevertheless, our main critic to all the papers is that no work tried to combine between a quantitative and a qualitative approach to give profound answers about the main issues related to IFRS for SMEs.

\section{- What is the future for IFRS for SMEs research?}

Citation Classics' authors about IFRS for SMEs predominately gave research future tails and questions that could be explored and studied about the standard. Some of them responded the call and some are and still a fertile ground to perform research. Svoboda, in 2011, called for a qualitative study about the applicability of every section of the standard by jurisdictions. The same for Schutte and Buys.

In 2012, Baldarelli et al. incited researchers to study the anthropological dimensions of the implementation process of the standard as well as SMEs attitude to adopt in a micro economic level to succeed transitioning to the standard.

In 2013, Albu et al. tried to answer to both, studying the anthropological dimensions and studying qualitatively the standard, and they were inspired from the institutional theory to explain how IFRS for SMEs could be implemented by taking into consideration 5 main stakeholder's view of this matter with a qualitative methodology. As for them, they opened a whole another debate about the political perspective of adopting the standard. This was partially the object of respectively the work of Ram and Newsberry about the IASB due standard of IFRS for SMEs and the work of Devi and Samujh about the non-implication of developing economies' academics and SMEs. This instigates Ram and Newsberry to worry about the IASB priorities when elaborating the standards.

And finally Kaya and Koch called for a study of macro-economic dimensions of adopting the standard with providing further analysis about determinant and economic effect on SMEs.

\section{Conclusions}

During our work, we tried to proceed according to a structured approach based on rigorous rules and criteria in order to understand how the research is been developing on IFRS for 


\section{Ml Macrothink}

International Journal of Accounting and Financial Reporting

ISSN 2162-3082

2017, Vol. 7, No. 2

SMEs as well as authors contributions, critics and possible future path. Our article is of a big contribution to accounting research since, as far as we know, no article wrote a structured literature review about IFRS, which means that the existing literature reviews are possibly bias and doesn't respond to objectivity, measures of validity and reliability and finally to article impact's aspect. That is one of the greatest advantages and contributions to accounting research in a methodological standpoint.

Summerly, in section 2 we gave a brief presentation about this new approach of elaborating literature reviews that is Structured Literature Reviews, and its main advantages, objectivity, validity and reliability measures, article impact ...etc. Afterward, we outlined the steps followed to elaborate a SLR by presenting our methodology in section 3. We started by a research protocol to assess the course of action of our paper by providing details on the starting idea to develop our literature review. The goal is to make the study replicable which is so related to reliability. Right after, we choose in an object manner the papers to analyze which are Citation Classics that we located in Web of Science according the definition of Garfield (2016) through which a Citation Classics is a highly cited publication as identified by the Science Citation Index (SCI) the Social Sciences Citation Index (SSCI), or the Arts \& Humanities Citation Index ( $A \& H C I$ ). The next step is about impact analysis according to 3 bibliometric indicators (TC, CPY and H-Index). And after establishing the analytical framework divided according to our research questions, we gave to each unit of analysis a code that we used in our analysis. We also, tested reliability and internal and construct validity.

In section 4 we presented our main findings. The adoption phenomena are the most studied subject about IFRS for SMEs with $60 \%$ in terms of number of papers. It is also the one with the highest impact as 3 articles of 5 are in the top 5 impactful papers. As for the location, we notice that Eastern Europe is the most studied one with $40 \%$ in total papers compounded especially from developing economies. The question is, why Eastern Europe and not Africa for example? The answer is simple because Eastern European countries are more favorable to adopt IFRS for SMEs because of their proximity and economic link to EU, which mandatory adopts full IFRS. Albeit the quantitative methodology is the most used one, with 6 articles using it, but it is not the one with the highest rates is terms of impact. Qualitative methodology is the one with the highest impact with $45 \%$ in TC even though only 2 articles are using it. And for literature reviews, only one papers used this methodology.

The authors contributed to the development of IFRS for SMEs' research in different levels. In a methodological standpoint, we notice that some of them tried new approaches, like the qualitative methodology or modelization through Multiple Criteria Decision Making (MCDM) to understand more the adoption phenomena. And in an empirical standpoint, some authors analyze the content of the standard, others tried to study institutional resources about the standard (Due Standard or the EC consultation paper for example) using to a critical approach. But we notice that the adoption phenomena is the primary concern of researchers because it was studied according to many perspectives, like Stakeholders perspective, harmonization with a national GAAP, conditions of implementation, the link between adoption and information quality ...etc. 


\section{Ml Macrothink}

International Journal of Accounting and Financial Reporting

ISSN 2162-3082

2017, Vol. 7, No. 2

However, the paper presents some critics. The fact that authors generalized some of their finding made their study bias by the lack of external validity tests. Others didn't provide empirical evidences to ascertain their conclusion. But the primary critics that we have to the papers is that no one tried to fuse between a qualitative and a quantitative methodology to further make the analysis deeper and wider.

Moreover, the authors gave some future path to be studied, like the applicability of each section of the standard, the anthropological dimensions of implementation, SMEs attitude when transitioning towards IFRS for SMEs in a micro-economical level, the political perspective of adopting the standard and its effects and finally macro-economic dimensions as well as adoption determinants and its economic consequences on SMEs.

Our paper doesn't pretend to be exhaustive and presents as well some critics to be discussed. Firstly, we took into consideration only 11 articles, albeit they are considered as relevant articles but they can't respond to exhaustiveness criterion. Also, we didn't quantify the reliability degree, Krippendorff's $\alpha$ could be a very good remedy to the measure. Finally, we did not provide an external validity analysis to generalize our study; it would be of a greater contribution to the field if we did so.

Thus, the combination between a qualitative and quantitative methodology could be an important path to develop further analysis of IFRS for SMEs adoption. The latter could be the object of a review study of all the papers to understand how the scientific community is seeing the implementation process of the standard. And, the study of the adoption process but with taking into consideration conditions, scenarios, effects as well as direct and indirect stakeholders point of view of developing economies.

Ultimately, we conclude that SLR is a method that presents many advantages in elaborating a literature review as far as it allow a profound and an objective analysis because it takes into consideration a lot of essential criteria that a traditional literature review neglect, like the literature review protocol, article impact analysis, validity and reliability measures, analytical framework and data coding and finally developing critics and future research paths.

\section{References}

Albu, C.N., Albu, N., Fekete, P.P.S., Girbina, M.M., Selimoglu, S.K., Kovacs, D.M., ... Strouhal, J. (2013). Implementation of IFRS for SMEs in Emerging Economies: Stakeholder Perceptions in the Czech Republic, Hungary, Romania and Turkey. Journal of International Financial Management \& Accounting, 24(2).

Alvesson, M., \& Deetz, S. (2000). Doing Critical Management Research. Sage, London.

Arksey, H., \& O’Malley, L. (2005). Scoping studies: towards a methodological framework. International Journal of Social Research Methodology, 8(1), 19-32.

Baldarelli, M.G., Demartini, P., Mosnja-Skare, L., \& Paoloni, P. (2012). Accounting Harmonization for SME-S in Europe: Some Remarks on IFRS for SME-S and Empirical Evidences. Ekonomska Istrazivanja-Economic Research, 25. 


\section{MlMacrothink}

International Journal of Accounting and Financial Reporting

ISSN 2162-3082

2017, Vol. 7, No. 2

Baldi, S. (1998). Normative versus social constructivist processes in the allocation of citations: a network-analytic model. American Sociological Review, 63(6), 829-846.

Biemans, W., Griffin, A., \& Moenaert, R. (2010). In search of the classics: a study of the impact of JPIM papers from 1984 to 2003. Journal of Product Innovation Management, 27(4), 461-484.

Chand, P., Patel, A., \& White, M. (2015). Adopting International Financial Reporting Standards for Small and Medium-sized Enterprises. Australian Accounting Review, 25(2).

Cronin, P., Ryan, F., \& Coughlan, M. (2008). Undertaking a literature review: a step-by-step approach. The British Journal of Nursing, 17(1), 38-43.

Denyer, D., \& Tranfield, D. (2006). Using qualitative research synthesis to build an actionable knowledge base. Management Decision, 44(2), 213-227.

Devi, S.S., \& Samujh, R.H. (2015). The Political Economy of Convergence: The Case of IFRS for SMEs. Australian Accounting Review, 25(2).

Dumay, J. (2014). 15 years of the journal of intellectual capital and counting: a manifesto for transformational IC research. Journal of Intellectual Capital, 15(1), 2-37.

Garfield, E. (1977). Introducing Citation Classics: The human side of Scientific Reports. Essays of an Information Scientist, 3, 1-2.

Garfield, E. (1989, January). Citation classics and citation behavior revisited. Current Comments, 12, 3-8.

Garfield, E. (2016). What is a citation classic? Retrieved October $30^{\text {th }}$, 2016, from http://garfield.library.upenn.edu/classics.html

Guthrie, J., \& Parker, L. D. (2011). Reflections and projections 25 years of interdisciplinary perspectives on accounting, auditing and accountability research. Accounting, Auditing \& Accountability Journal, 25(1), 6-26.

Guthrie, J., Ricceri, F., \& Dumay, J. (2012). Reflections and projections: a decade of intellectual capital accounting research. The British Accounting Review, 44(2), 68-82.

Hart, C. (1998). Doing Literature Review: Releasing the Social Science Research Imagination. Sage Publications, London.

Harzing, A.W., \& Alakangas, S. (2016). Google Scholar, Scopus and the Web of Science: A longitudinal and cross-disciplinary comparison. Scientometrics, 106(2), 787-804.

Hayes, A.F., \& Krippendorff, K. (2007). Answering the call for a standard reliability measure for coding data. Communication Methods and Measures, 1(1), 77-89.

Kaya, D., \& Koch, M. (2015). Countries' adoption of the International Financial Reporting Standard for Small and Medium-sized Entities (IFRS for SMEs) - early empirical evidence. Accounting and Business Research, 45(1). 


\section{MInstitute Macrothink $_{\text {Int }}$}

International Journal of Accounting and Financial Reporting

ISSN 2162-3082

Krippendorff, K. (2004). Content Analysis. An Introduction to Its Methodology (2nd ed.). Sage Publications, Thousand Oaks, CA.

Liu, J.Y., \& Lee, M.S. (2015). MCDM Approach for the Adoption of IFRS for SMEs: Using Taiwan as an Example. Journal of Testing and Evaluation, 43(4).

Martınez, M.A., Herrera, M., Lopez-Gijon, J., \& Herrera-Viedma, E. (2013). H-Classics: characterizing the concept of citation classics through H-index. Scientometrics, 98, 1971-1983.

Massaro, M., Dumay, J., \& Guthrie, J. (2016). On the shoulders of giants: undertaking a structured literature review in accounting. Accounting, Auditing \& Accountability Journal, 29(5), 767-801.

Newberry, S. (2015). Public sector accounting: shifting concepts of accountability. Public Money \& Management, 35(5).

Organisation of Economic and Cooperation Development. (2004). Les dossiers du CAD. Revue de l'OCDE sur le développement, 2(5), Volume 5-2, Chapter 1, Page 38, Section 1.

Petticrew, M., \& Roberts, H. (2008). Systematic Reviews in the Social Sciences: A Practical Guide, Kindle (ed.). Wiley-Blackwell, Oxford.

Ram, R., Newberry, S. (2013). IFRS for SMEs: The Iasb's Due Process. Australian Accounting Review, 23(1).

Schildbach, T. (2013). The European Commission's Consultation on IFRS for SMEs analysis and conclusions. Betriebswirtschaftliche Forschung Und Praxis, 65(1).

Schutte, D., \& Buys, P. (2011). A Critical Analysis of the Contents of the IFRS for SMEs - A South African Perspective. South African Journal of Economic and Management Sciences, 14(2).

Silverman, D. (2013). Doing Qualitative Research. Sage Publications, London.

Stanley, T. (2001). Wheat from chaff: meta-analysis as quantitative literature review. Journal of Economic Perspectives, 15(3), 131-150.

Svoboda, P. (2011). Application of new approaches in recognizing leases on the part of the lessee in the selected companies in the Czech Republic. Agricultural Economics-Zemedelska Ekonomika, 57(7).

Tranfield, D., Denyer, D., \& Smart, P. (2003). Towards a methodology for developing evidence informed management knowledge by means of systematic review. British Journal of Management, 14(3), 207-222.

White, T., \& McBurney, D. (2012). Research Method (9th ed.) Wadsworth, Belmont, CA.

Yin, R.K. (2014). Case Study Research: Design and Methods (5th ed.). SAGE, Los Angeles, CA. 


\section{1) Macrothink \\ International Journal of Accounting and Financial Reporting \\ ISSN 2162-3082 \\ 2017, Vol. 7, No. 2}

\section{Appendixes}

Appendix 1. Results of the query on Web of Science of the theme IFRS for SMEs between 2009 and 2015 on SCI, SSCI and A\&HCI

Title

Implementation of IFRS for SMEs in Emerging

Economies: Stakeholder Perceptions in the

Czech Republic, Hungary, Romania and

Turkey

Public sector accounting: shifting concepts of

accountability

IFRS FOR SMEs: THE IASB'S DUE

PROCESS

Countries' adoption of the International

Financial Reporting Standard for Small and

Medium-sized Entities (IFRS for SMEs) - early

empirical evidence

ACCOUNTING HARMONIZATION FOR

SME-S IN EUROPE: SOME REMARKS ON

IFRS FOR SME-S AND EMPIRICAL

EVIDENCES

A CRITICAL ANALYSIS OF THE CONTENTS

OF THE IFRS FOR SMES - A SOUTH

AFRICAN PERSPECTIVE

MCDM Approach for the Adoption of IFRS for

SMEs: Using Taiwan as an Example

The Political Economy of Convergence: The

Case of IFRS for SMEs

Adopting International Financial Reporting

Standards for Small and Medium-sized

Enterprises

The European Commission's Consultation on

IFRS for SMEs - analysis and conclusions

Application of new approaches in recognizing

leases on the part of the lessee in the selected

companies in the Czech Republic
Authors
Albu, Catalin Nicolae; Albu, Nadia; Pali-Pista,

Szilveszter Fekete; Girbina, Maria Madalina;

Selimoglu, Seval Kardes; Kovacs, Daniel Mate;

Lukacs, Janos; Mohl, Gergely; Muellerova,

Libuse; Pasekova, Marie; Arsoy, Aylin Poroy;

Sipahi, Baris; Strouhal, Jiri

Newberry, Susan

Ram, Ronita; Newberry, Susan

Kaya, Devrimi; Koch, Maximilian

Baldarelli, Maria-Gabriella; Demartini, Paola;

Mosnja-Skare, Lorena; Paoloni, Paola

Schutte, Danie; Buys, Pieter

Liu, Jau-Yang; Lee, Mu-Shang

Devi, S. Susela; Samujh, R. Helen

Chand, Parmod; Patel, Arvind; White, Michael

Schildbach, Thomas

Svoboda, Patrik
Source

JOURNAL OF

INTERNATIONAL

FINANCIAL

MANAGEMENT \&

ACCOUNTING

PUBLIC MONEY \&

MANAGEMENT

AUSTRALIAN

ACCOUNTING REVIEW

ACCOUNTING AND

BUSINESS RESEARCH

EKONOMSKA

ISTRAZIVANJA-ECONOMI

C RESEARCH

SOUTH AFRICAN

JOURNAL OF ECONOMIC

AND MANAGEMENT

SCIENCES

JOURNAL OF TESTING

AND EVALUATION

AUSTRALIAN

ACCOUNTING REVIEW

AUSTRALIAN

ACCOUNTING REVIEW

BETRIEBSWIRTSCHAFTLI

CHE FORSCHUNG UND

PRAXIS

AGRICULTURAL

ECONOMICS-ZEMEDELSK

A EKONOMIKA
Year Vol. Issue TC CPY

$\begin{array}{lllll}2013 & 24 & 2 & 9 & 2,25\end{array}$

$2015 \quad 35$

$2013 \quad 23$

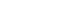

$2015 \quad 45$

$2012 \quad 25$

20,4

0,33

$2015 \quad 43$

$2015 \quad 25$

$2015 \quad 25$

$2013 \quad 65 \quad 1 \quad 000$

(n)

$\begin{array}{lllll}2011 & 57 & 7 & 0 & 0\end{array}$ 


\section{Macrothink}

International Journal of Accounting and Financial Reporting

ISSN 2162-3082

2017, Vol. 7, No. 2

Appendix 2. Bibliometric indicators for the analysis of the impact of articles

\begin{tabular}{|c|c|c|c|}
\hline Articles & TC & CPY & H-Index \\
\hline Implementation of IFRS for SMEs in Emerging Economies: Stakeholder Perceptions in the Czech Republic, Hungary, Romania and Turkey & 25 & 8,33 & 1 \\
\hline IFRS FOR SMES: THE IASB'S DUE PROCESS & 12 & 4 & 1 \\
\hline A CRITICAL ANALYSIS OF THE CONTENTS OF THE IFRS FOR SMES - A SOUTH AFRICAN PERSPECTIVE & 9 & 1,8 & 1 \\
\hline Countries' adoption of the International Financial Reporting Standard for Small and Medium-sized Entities (IFRS for SMEs) - early empirical evidence & 8 & 2 & 2 \\
\hline ACCOUNTING HARMONIZATION FOR SME-S IN EUROPE: SOME REMARKS ON IFRS FOR SME-S AND EMPIRICAL EVIDENCES & 5 & 1 & 1 \\
\hline Public sector accounting: shifting concepts of accountability & 4 & 4 & 1 \\
\hline Adopting International Financial Reporting Standards for Small and Medium-sized Enterprises & 1 & 1 & 1 \\
\hline Application of new approaches in recognizing leases on the part of the lessee in the selected companies in the Czech Republic & 1 & 0,2 & 1 \\
\hline MCDM Approach for the Adoption of IFRS for SMEs: Using Taiwan as an Example & 0 & 0 & 0 \\
\hline The Political Economy of Convergence: The Case of IFRS for SMEs & 0 & 0 & 0 \\
\hline The European Commission's Consultation on IFRS for SMEs - analysis and conclusions & 0 & 0 & 0 \\
\hline
\end{tabular}

Appendix 3. Bibliometric indicators for the analysis of the impact of authors

\begin{tabular}{|c|c|c|c|c|}
\hline Articles & Authors & $\mathbf{T C}$ & CPY & H-Index \\
\hline $\begin{array}{l}\text { Implementation of IFRS for SMEs in Emerging Economies: Stakeholder Perceptions in } \\
\text { the Czech Republic, Hungary, Romania and Turkey }\end{array}$ & $\begin{array}{l}\text { Albu, Catalin Nicolae; Albu, Nadia; Pali-Pista, Szilveszter } \\
\text { Fekete; Girbina, Maria Madalina; Selimoglu, Seval Kardes; } \\
\text { Kovacs, Daniel Mate; Lukacs, Janos; Mohl, Gergely; } \\
\text { Muellerova, Libuse; Pasekova, Marie; Arsoy, Aylin Poroy; } \\
\text { Sipahi, Baris; Strouhal, Jiri }\end{array}$ & 4173 & 226,95 & 112 \\
\hline $\begin{array}{l}\text { The European Commission's Consultation on IFRS for SMEs - analysis and } \\
\text { conclusions }\end{array}$ & Schildbach, Thomas & 2860 & 65,00 & 28 \\
\hline IFRS FOR SMEs: THE IASB'S DUE PROCESS & Ram, Ronita; Newberry, Susan & 962 & 41,65 & 19 \\
\hline $\begin{array}{l}\text { ACCOUNTING HARMONIZATION FOR SME-S IN EUROPE: SOME REMARKS ON } \\
\text { IFRS FOR SME-S AND EMPIRICAL EVIDENCES }\end{array}$ & $\begin{array}{l}\text { Baldarelli, Maria-Gabriella; Demartini, Paola; } \\
\text { Mosnja-Skare, Lorena; Paoloni, Paola }\end{array}$ & 635 & 30,57 & 27 \\
\hline $\begin{array}{l}\text { Adopting International Financial Reporting Standards for Small and Medium-sized } \\
\text { Enterprises }\end{array}$ & Chand, Parmod; Patel, Arvind; White, Michael & 6 & 27,40 & 11 \\
\hline MCDM Approach for the Adoption of IFRS for SMEs: Using Taiwan as an Example & Liu, Jau-Yang; Lee, Mu-Shang & 273 & 22,75 & 8 \\
\hline $\begin{array}{l}\text { Countries' adoption of the International Financial Reporting Standard for Small and } \\
\text { Medium-sized Entities (IFRS for SMES) - early empirical evidence }\end{array}$ & Kaya, Devrimi; Koch, Maximilian & 225 & 8,92 & 12 \\
\hline The Political Economy of Convergence: The Case of IFRS for SMEs & Devi, S. Susela; Samujh, R. Helen & 145 & 10,76 & 8 \\
\hline $\begin{array}{l}\text { Application of new approaches in recognizing leases on the part of the lessee in the } \\
\text { selected companies in the Czech Republic }\end{array}$ & Svoboda, Patrik & 68 & 7,56 & 4 \\
\hline
\end{tabular}




\section{Macrothink \\ International Journal of Accounting and Financial Reporting \\ ISSN 2162-3082 \\ 2017, Vol. 7, No. 2}

Appendix 4. Bibliometric indicators for the analysis of the impact of the journals

\begin{tabular}{|c|c|c|c|c|}
\hline Articles & Journals & $\mathbf{T C}$ & CPY & H-Index \\
\hline $\begin{array}{l}\text { Countries' adoption of the International Financial Reporting Standard for Small } \\
\text { and Medium-sized Entities (IFRS for SMEs) - early empirical evidence }\end{array}$ & ACCOUNTING AND BUSINESS RESEARCH & 47325 & 1028,80 & 105 \\
\hline Public sector accounting: shifting concepts of accountability & PUBLIC MONEY MANAGEMENT & 23547 & 672,77 & 66 \\
\hline MCDM Approach for the Adoption of IFRS for SMEs: Using Taiwan as an Example & JOURNAL OF TESTING AND EVALUATION & 20878 & 485,53 & 60 \\
\hline $\begin{array}{l}\text { Implementation of IFRS for SMEs in Emerging Economies: Stakeholder Perceptions } \\
\text { in the Czech Republic, Hungary, Romania and Turkey }\end{array}$ & $\begin{array}{l}\text { JOURNAL OF INTERNATIONAL FINANCIAL } \\
\text { MANAGEMENT \& ACCOUNTING }\end{array}$ & 13585 & 452,83 & 62 \\
\hline $\begin{array}{l}\text { The European Commission's Consultation on IFRS for SMEs - analysis and } \\
\text { conclusions }\end{array}$ & $\begin{array}{l}\text { BETRIEBSWIRTSCHAFTLICHE FORSCHUNG } \\
\text { UND PRAXIS }\end{array}$ & 11844 & 176,78 & 48 \\
\hline IFRS FOR SMES: THE IASB'S DUE PROCESS & AUSTRALIAN ACCOUNTING REVIEW & 9282 & 371,28 & 46 \\
\hline The Political Economy of Convergence: The Case of IFRS for SMEs & AUSTRALIAN ACCOUNTING REVIEW & 9282 & 371,28 & 46 \\
\hline $\begin{array}{l}\text { Adopting International Financial Reporting Standards for Small and Medium-sized } \\
\text { Enterprises }\end{array}$ & AUSTRALIAN ACCOUNTING REVIEW & 9282 & 371,28 & 46 \\
\hline $\begin{array}{l}\text { A CRITICAL ANALYSIS OF THE CONTENTS OF THE IFRS FOR SMES - A } \\
\text { SOUTH AFRICAN PERSPECTIVE }\end{array}$ & $\begin{array}{l}\text { SOUTH AFRICAN JOURNAL OF ECONOMIC AND } \\
\text { MANAGEMENT SCIENCES }\end{array}$ & 3208 & 118,81 & 23 \\
\hline
\end{tabular}

Appendix 5. Ranking of IFRS for SMEs' Citation Classics in terms of TC

\begin{tabular}{|c|c|c|c|c|c|c|c|c|}
\hline \multirow{2}{*}{ Articles } & \multicolumn{3}{|c|}{ TOTAL CITATIONS } & \multicolumn{3}{|c|}{ RANKING OF } & \multirow{2}{*}{ TOTAL } & \multirow{2}{*}{$\begin{array}{l}\text { TC } \\
\text { RANKING }\end{array}$} \\
\hline & Articles & Authors & Journals & Articles & Authors & Journals & & \\
\hline $\begin{array}{l}\text { A CRITICAL ANALYSIS OF THE CONTENTS OF THE IFRS FOR SMES - A SOUTH } \\
\text { AFRICAN PERSPECTIVE }\end{array}$ & 9 & 124 & 3208 & 3 & 9 & 9 & 21 & 6 \\
\hline $\begin{array}{l}\text { ACCOUNTING HARMONIZATION FOR SME-S IN EUROPE: SOME REMARKS ON } \\
\text { IFRS FOR SME-S AND EMPIRICAL EVIDENCES }\end{array}$ & 5 & 635 & 15 & 5 & 5 & 11 & 21 & 6 \\
\hline $\begin{array}{l}\text { Adopting International Financial Reporting Standards for Small and Medium-sized } \\
\text { Enterprises }\end{array}$ & 1 & 6 & 9282 & 7 & 11 & 8 & 26 & 7 \\
\hline $\begin{array}{l}\text { Application of new approaches in recognizing leases on the part of the lessee in the } \\
\text { selected companies in the Czech Republic }\end{array}$ & 1 & 68 & 163 & 8 & 10 & 10 & 28 & 8 \\
\hline $\begin{array}{l}\text { Countries' adoption of the International Financial Reporting Standard for Small and } \\
\text { Medium-sized Entities (IFRS for SMEs) - early empirical evidence }\end{array}$ & 8 & 225 & 47325 & 4 & 7 & 1 & 12 & 3 \\
\hline IFRS FOR SMES: THE IASB'S DUE PROCESS & 12 & 962 & 9282 & 2 & 3 & 6 & 11 & 2 \\
\hline $\begin{array}{l}\text { Implementation of IFRS for SMEs in Emerging Economies: Stakeholder Perceptions in } \\
\text { the Czech Republic, Hungary, Romania and Turkey }\end{array}$ & 25 & 4173 & 13585 & 1 & 1 & 4 & 6 & 1 \\
\hline MCDM Approach for the Adoption of IFRS for SMEs: Using Taiwan as an Example & 0 & 273 & 20878 & 9 & 6 & 3 & 18 & 5 \\
\hline Public sector accounting: shifting concepts of accountability & 4 & 940 & 23547 & 6 & 4 & 2 & 12 & 3 \\
\hline $\begin{array}{l}\text { The European Commission's Consultation on IFRS for SMEs - analysis and } \\
\text { conclusions }\end{array}$ & 0 & 2860 & 11844 & 10 & 2 & 5 & 17 & 4 \\
\hline The Political Economy of Convergence: The Case of IFRS for SMEs & 0 & 145 & 9282 & 11 & 8 & 7 & 26 & 7 \\
\hline
\end{tabular}




\section{1) Macrothink \\ International Journal of Accounting and Financial Reporting \\ ISSN 2162-3082 \\ 2017, Vol. 7, No. 2}

Appendix 6. Ranking of IFRS for SMEs' Citation Classics in terms of CPY

Articles

\begin{tabular}{cccccc}
\multicolumn{2}{c}{ CITATION PER YEAR } & \multicolumn{2}{c}{ RANKING OF } \\
\cline { 1 - 4 } Articles & Authors & Journals & Articles & Authors & Journals
\end{tabular}

CPY RANKING

A CRITICAL ANALYSIS OF THE CONTENTS OF THE IFRS FOR SMES - A SOUTH AFRICAN PERSPECTIVE

ACCOUNTING HARMONIZATION FOR SME-S IN EUROPE: SOME REMARKS ON IFRS FOR SME-S AND EMPIRICAL EVIDENCES

$\begin{array}{llllllll}1,8 & 4 & 119 & 5 & 5 & 9 & 19 & \mathbf{6}\end{array}$

Adopting International Financial Reporting Standards for Small and Medium-sized

Enterprises

Application of new approaches in recognizing leases on the part of the lessee in the selected companies in the Czech Republic

$\begin{array}{llllllll}1,8 & 4 & 119 & 5 & 5 & 9 & 19 & \mathbf{6}\end{array}$

\begin{tabular}{|c|c|c|c|c|c|c|}
\hline 1 & 31 & 1 & 7 & 7 & 1 & 8 \\
\hline
\end{tabular}

Countries' adoption of the International Financial Reporting Standard for Small and Medium-sized Entities (IFRS for SMEs) - early empirical evidence

Implementation of IFRS for SMEs in Emerging Economies: Stakeholder Perceptions in the Czech Republic, Hungary, Romania and Turkey

27

$371 \quad 6$

6

6

18

5

\begin{tabular}{|c|c|c|c|c|c|c|c|c|}
\hline MCDM Approach for the Adoption of IFRS for SMEs: Using Taiwan as an Example & 0 & 23 & 486 & 9 & 9 & 3 & 21 & 7 \\
\hline Public sector accounting: shifting concepts of accountability & 4 & 36 & 673 & 2 & 2 & 2 & 6 & 1 \\
\hline
\end{tabular}

The European Commission's Consultation on IFRS for SMEs - analysis and conclusions

The Political Economy of Convergence: The Case of IFRS for SMEs

$\begin{array}{llllllll}0 & 65 & 177 & 11 & 11 & 8 & 30 & \mathbf{1 1}\end{array}$

0

11

371

10

10

27

10

Appendix 7. Ranking of IFRS for SMEs' Citation Classics in terms of H-Index

\begin{tabular}{|c|c|c|c|c|c|c|c|c|}
\hline \multirow{2}{*}{ Articles } & \multicolumn{3}{|c|}{ H-INDEX } & \multicolumn{3}{|c|}{ RANKING OF } & \multirow{2}{*}{ TOTAL } & \multirow{2}{*}{$\begin{array}{l}\text { H-INDEX } \\
\text { RANKING }\end{array}$} \\
\hline & Articles & Authors & Journals & Articles & Authors & Journals & & \\
\hline $\begin{array}{l}\text { A CRITICAL ANALYSIS OF THE CONTENTS OF THE IFRS FOR SMES - A SOUTH } \\
\text { AFRICAN PERSPECTIVE }\end{array}$ & 1 & 9 & 23 & 2 & 8 & 9 & 19 & 9 \\
\hline $\begin{array}{l}\text { ACCOUNTING HARMONIZATION FOR SME-S IN EUROPE: SOME REMARKS ON } \\
\text { IFRS FOR SME-S AND EMPIRICAL EVIDENCES }\end{array}$ & 1 & 27 & 3 & 2 & 3 & 11 & 16 & 7 \\
\hline $\begin{array}{l}\text { Adopting International Financial Reporting Standards for Small and Medium-sized } \\
\text { Enterprises }\end{array}$ & 1 & 11 & 46 & 2 & 7 & 7 & 16 & 6 \\
\hline $\begin{array}{l}\text { Application of new approaches in recognizing leases on the part of the lessee in the } \\
\text { selected companies in the Czech Republic }\end{array}$ & 1 & 4 & 7 & 2 & 11 & 10 & 23 & 11 \\
\hline $\begin{array}{l}\text { Countries' adoption of the International Financial Reporting Standard for Small and } \\
\text { Medium-sized Entities (IFRS for SMEs) - early empirical evidence }\end{array}$ & 2 & 12 & 105 & 1 & 6 & 1 & 8 & 2 \\
\hline IFRS FOR SMES: THE IASB'S DUE PROCESS & 1 & 19 & 46 & 2 & 4 & 6 & 12 & 5 \\
\hline $\begin{array}{l}\text { Implementation of IFRS for SMEs in Emerging Economies: Stakeholder Perceptions in } \\
\text { the Czech Republic, Hungary, Romania and Turkey }\end{array}$ & 1 & 112 & 62 & 2 & 1 & 3 & 6 & 1 \\
\hline MCDM Approach for the Adoption of IFRS for SMEs: Using Taiwan as an Example & 0 & 8 & 60 & 3 & 9 & 4 & 16 & 8 \\
\hline Public sector accounting: shifting concepts of accountability & 1 & 17 & 66 & 2 & 5 & 2 & 9 & 3 \\
\hline The European Commission's Consultation on IFRS for SMEs - analysis and & 0 & 28 & 48 & 3 & 2 & 5 & 10 & 4 \\
\hline
\end{tabular}




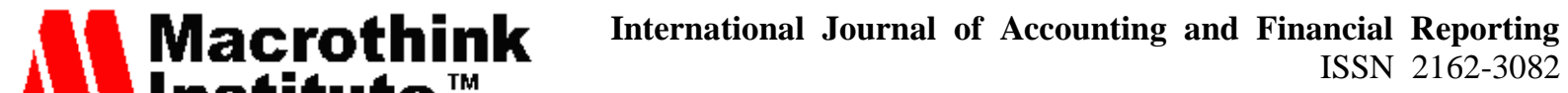

Appendix 8. Analycial table summarizing the results of Citation Classics' analytical framework on IFRS for SMEs

\begin{tabular}{|c|c|c|c|c|c|c|c|}
\hline \multirow[t]{2}{*}{ Year } & \multirow[t]{2}{*}{ Articles } & How is rese & SMEs develop & ing? & \multicolumn{2}{|c|}{ What is the focus and critique of the IFRS for SMEs literature? } & \multirow{2}{*}{$\begin{array}{l}\text { What is the future for IFRS for } \\
\qquad \text { SMEs research? } \\
\text { Future path }\end{array}$} \\
\hline & & Subject & Location & Methodology & Contributions & Limits and Critics & \\
\hline 2013 & $\begin{array}{l}\text { Implementation of IFRS } \\
\text { for SMEs in Emerging } \\
\text { Economies: Stakeholder } \\
\text { Perceptions in the Czech } \\
\text { Republic, Hungary, } \\
\text { Romania and Turkey }\end{array}$ & Adoption & $\begin{array}{l}\text { Czech } \\
\text { Republic, } \\
\text { Hungary, } \\
\text { Romania } \\
\text { and Turkey }\end{array}$ & $\begin{array}{l}\text { Qualitative } \\
\text { (interviews) }\end{array}$ & $\begin{array}{l}\text { - Wider target than previous } \\
\text { studies } \\
\text { - Opposite opinions according to } \\
\text { stakeholders' profile } \\
\text { - Establishing } 3 \text { implementation } \\
\text { scenarios using a isomorphism }\end{array}$ & $\begin{array}{l}\text { - Absence of empirical evidence } \\
\text { related to advantages, effects and } \\
\text { costs of implementation }\end{array}$ & $\begin{array}{l}\text { - Studying the implementation } \\
\text { process of the standard from the } \\
\text { political perspective }\end{array}$ \\
\hline 2015 & $\begin{array}{l}\text { Public sector accounting: } \\
\text { shifting concepts of } \\
\text { accountability }\end{array}$ & $\begin{array}{l}\text { IFRS for } \\
\text { SMEs and } \\
\text { public } \\
\text { sector }\end{array}$ & Australia & $\begin{array}{c}\text { Documentary } \\
\text { study }\end{array}$ & $\begin{array}{l}\text { - Commentaries on accounting in } \\
\text { the public sector according on } \\
\text { IFRS for SMEs and its } \\
\text { relationship with accountability }\end{array}$ & $\begin{array}{l}\text { - It's much more a commentary } \\
\text { than a research study }\end{array}$ & $\begin{array}{l}\text { - Empirical evidence on the use } \\
\text { of IFRS for SMEs in the public } \\
\text { sector }\end{array}$ \\
\hline 2013 & $\begin{array}{l}\text { IFRS FOR SMEs: THE } \\
\text { IASB'S DUE PROCESS }\end{array}$ & $\begin{array}{l}\text { Institutional } \\
\text { resources } \\
\text { analysis of } \\
\text { IFRS for } \\
\text { SMEs }\end{array}$ & & $\begin{array}{l}\text { - Documentary } \\
\text { study } \\
\text { - Qualitative } \\
\text { (interviews) }\end{array}$ & $\begin{array}{l}\text { - Critical study about the IASB } \\
\text { due process of the standard } \\
\text { - The study demonstrates that the } \\
\text { IASB didn't respect the public } \\
\text { side of its Due process started, by } \\
\text { maintaining in an engaged manner } \\
\text { recognition and measurement } \\
\text { requirements of full IFRS }\end{array}$ & $\begin{array}{l}\text { - Absence of validity and } \\
\text { reliability measures } \\
\text { - Absence of quantitative data } \\
\text { - The findings were generalized } \\
\text { without testing external validity } \\
\text { (like the comparison between a } \\
\text { due process of another standard. }\end{array}$ & $\begin{array}{l}\text { - Empirical study about IASB } \\
\text { priorities by studying the issuing } \\
\text { process of the other standards. }\end{array}$ \\
\hline 2015 & $\begin{array}{l}\text { Countries' adoption of } \\
\text { the International } \\
\text { Financial Reporting } \\
\text { Standard for Small and } \\
\text { Medium-sized Entities } \\
\text { (IFRS for SMEs) - early } \\
\text { empirical evidence }\end{array}$ & Adoption & $\begin{array}{l}\text { Sample of } \\
128 \text { country }\end{array}$ & Quantitative & $\begin{array}{l}\text { - Counties that doesn't have the } \\
\text { capacity to develop their own } \\
\text { GAAP as well as the countries } \\
\text { that they already adopted full } \\
\text { IFRS are more favorable to adopt } \\
\text { IFRS for SMEs } \\
\text { - There is a positive link between } \\
\text { information quality and IFRS for } \\
\text { SMEs adoption } \\
\text { - IFRS for SMEs is more adopted } \\
\text { by developing economies rather } \\
\text { than developed economies. }\end{array}$ & $\begin{array}{l}\text { - Data were collected on the basis } \\
\text { of IASB's informations about } \\
\text { IFRS for SMEs implementation. } \\
\text { So the data collected is of a lower } \\
\text { relevance and reliability } \\
\text { - The discloser process of the } \\
\text { standard is still ongoing, so the } \\
\text { findings of our study may not be } \\
\text { definitive as far as the adopting } \\
\text { countries is increasing. }\end{array}$ & $\begin{array}{l}\text { - Study of the macroeconomic } \\
\text { effects of IFRS for SMEs } \\
\text { adoption. } \\
\text { - Study of the manner with which } \\
\text { jurisdictions implement the } \\
\text { standard - Analysis of the } \\
\text { determinants and economic } \\
\text { consequences of IFRS for SMEs } \\
\text { adoption. }\end{array}$ \\
\hline 2012 & $\begin{array}{l}\text { ACCOUNTING } \\
\text { HARMONIZATION } \\
\text { FOR SME-S IN } \\
\text { EUROPE: SOME } \\
\text { REMARKS ON IFRS } \\
\text { FOR SME-S AND } \\
\text { EMPIRICAL } \\
\text { EVIDENCES }\end{array}$ & Adoption & Croatia & Quantitative & $\begin{array}{l}\text { - Empirical study of Croatian } \\
\text { GAAP harmonization with IFRS } \\
\text { for SMEs }\end{array}$ & $\begin{array}{l}\text { - The quantitative study is based } \\
\text { only on descriptive statistics } \\
\text { without providing further } \\
\text { profound explanations about the } \\
\text { reasons behind harmonization }\end{array}$ & $\begin{array}{l}\text { - Study of the anthropological } \\
\text { dimensions to take into } \\
\text { consideration when implementing } \\
\text { IFRS for SMEs } \\
\text { - Study of SMEs attitude in formal } \\
\text { or informal relations to survive in } \\
\text { international trade }\end{array}$ \\
\hline
\end{tabular}




\section{Macrothink}

International Journal of Accounting and Financial Reporting

ISSN 2162-3082

2017, Vol. 7, No. 2

\section{A CRITICAL}

2011

$\begin{array}{lcc}\text { ANALYSIS OF THE } & \text { Content } & \\ \text { CONTENTS OF THE } & \text { Analysis of } & \text { South } \\ \text { IFRS FOR SMES - A } & \text { IFRS for } & \text { Africa } \\ \text { SOUTH AFRICAN } & \text { SMEs } & \\ \text { PERSPECTIVE } & & \end{array}$

\begin{tabular}{|c|c|c|c|}
\hline \multirow[b]{2}{*}{ Quantitative } & - Content study of IFRS for & & \\
\hline & $\begin{array}{l}\text { SMEs from professionals and } \\
\text { professional interns standpoint } \\
\text { - The balance sheet statement and } \\
\text { profit and loss statement is the } \\
\text { most used financial statements by } \\
\text { sub African professionals } \\
\text { - Based on the fact that sub } \\
\text { African SMEs doesn't resort to } \\
\text { financial markets and } \\
\text { subsequently foreign investors } \\
\text { doesn't invest in sub African } \\
\text { SMEs }\end{array}$ & $\begin{array}{l}\text { - The article didn't give a direct } \\
\text { answer to the eventual limits and } \\
\text { critics, in the methodological or } \\
\text { the empirical level. } \\
\text { - Neither it did not gave some } \\
\text { future research path } \\
\text { - The sample is not } \\
\text { representative of all the } \\
\text { stakeholders implied in IFRS for } \\
\text { SMEs Reporting process. }\end{array}$ & $\begin{array}{l}\text { - Qualitative methodology in } \\
\text { studying IFRS for SMEs by using } \\
\text { the content analysis technique/ }\end{array}$ \\
\hline Quantitative & $\begin{array}{l}\text { - The study gave } 3 \text { manners of } \\
\text { adopting IFRS for SMEs as well } \\
\text { as a new quantitative approach to } \\
\text { modeling the adoption process of } \\
\text { a certain country. } \\
\text { - Le study is considered as a } \\
\text { model to the MCDM Approach } \\
\text { regarding IFRS for SMEs } \\
\text { adoption }\end{array}$ & $\begin{array}{l}\text { - Generalization of the model to } \\
\text { all the jurisdictions based only on } \\
\text { a single case study without testing } \\
\text { external validity }\end{array}$ & N/A \\
\hline
\end{tabular}

- Study of the conceptual framework of financial markets

Institutional

The Political Economy resources

2015 of Convergence: The

analysis of

Case of IFRS for SMEs IFRS for

SMEs
- Analysis of the academics and developing economies SMEs Literature review participation in elaborating IFRS for SMEs and their components adaptation

- Study of IFRS for SMEs users
- Absence of an empirical confirming the findings qualitative or quantitative study and their needs

- Study of the convergence effects on developing economies

- Study of IFRS for SMEs

pre-adoption in developing

economies

\begin{tabular}{|c|c|c|c|c|c|c|c|}
\hline \multirow{5}{*}{2015} & Adopting International & \multirow{5}{*}{ Adoption } & \multirow{5}{*}{ Fiji } & \multirow{5}{*}{ Quantitative } & \multirow{4}{*}{$\begin{array}{l}\text { - The study is considered as } \\
\text { impulsive element to succeed } \\
\text { convergence towards IFRS for } \\
\text { SMEs and provides answers about }\end{array}$} & - The study was performed only & \multirow{3}{*}{$\begin{array}{l}\text { - Empirical and conceptual } \\
\text { evaluation of IFRS for SMEs } \\
\text { - Study on other geographical }\end{array}$} \\
\hline & Financial Reporting & & & & & & \\
\hline & Standards for Small and & & & & & & \\
\hline & Medium-sized & & & & & other stakeholders, like users & areas and with other SMEs GAAP \\
\hline & Enterprises & & & & jurisdictions eventual issues. & auditors, ...etc. & in order to generalize the findings. \\
\hline \multirow{5}{*}{2013} & The European & Institutional & \multirow{5}{*}{ N/A } & \multirow{5}{*}{ N/A } & \multirow{5}{*}{ N/A } & \multirow{5}{*}{ N/A } & \multirow{5}{*}{ N/A } \\
\hline & Commission's & resources & & & & & \\
\hline & Consultation on IFRS for & analysis of & & & & & \\
\hline & SMEs - analysis and & IFRS for & & & & & \\
\hline & conclusions (Note 5) & SMEs & & & & & \\
\hline
\end{tabular}




\begin{tabular}{lc}
$\begin{array}{l}\text { Application of new } \\
\text { approaches in }\end{array}$ & \multicolumn{1}{c}{ Content } \\
recognizing leases on the & Analysis of \\
part of the lessee in the & IFRS for \\
selected companies in the & SMEs \\
Czech Republic & (Leasing)
\end{tabular}
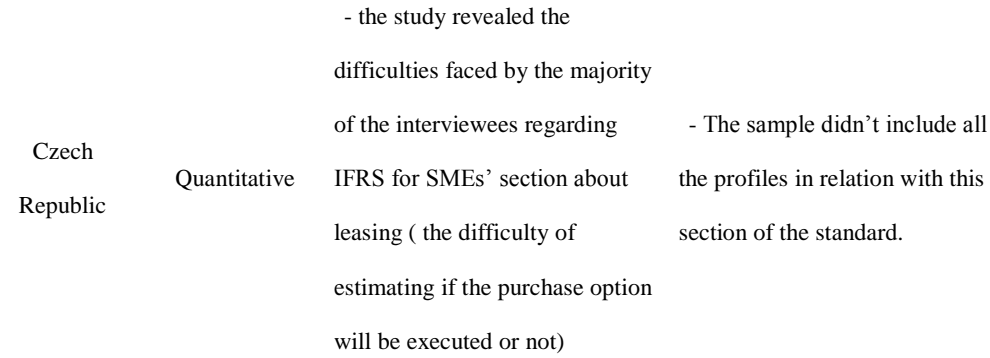

\section{Notes}

Note 1. SMEs constitute more than $95 \%$ in OECD economies and employs between $60 \%$ and $70 \%$ of the population.

Note 2. Total Citations is the total number of citations since the publication year of an article to the year of analysis.

Note 3. Citation per Year is Total Citation divided by the number of year between the publication year and the year of analysis.

Note 4. A scientist has index $\mathrm{h}$ if $\mathrm{h}$ of his or her Np papers have at least $\mathrm{h}$ citations each, and the other $(\mathrm{Np}-\mathrm{h})$ papers have $\leq \mathrm{h}$ citations each. It identifies the most productive core of an author's output in terms of the most cited papers.

Note 5. This article is not available.

\section{Copyright Disclaimer}

Copyright for this article is retained by the author(s), with first publication rights granted to the journal.

This is an open-access article distributed under the terms and conditions of the Creative Commons Attribution license (http://creativecommons.org/licenses/by/4.0/) 